\title{
Educational Speech-Language Pathology in the curricula of Speech-Language Pathology Programs in Brazil
}

Chirlene Santos da Cunha Moura ${ }^{1}$ https://orcid.org/0000-0002-3650-6383

Girlany Santana de Moura² https://orcid.org/0000-0003-4974-5858

Ivonaldo Leidson Barbosa Lima ${ }^{1}$ https://orcid.org/0000-0003-1716-1575

Ariana Elite dos Santos ${ }^{1}$ https://orcid.org/0000-0003-1723-7074

Maiara dos Santos Sousa ${ }^{3}$ https://orcid.org/0000-0002-7605-7500

Luciana Figueiredo de Oliveira ${ }^{4}$ https://orcid.org/0000-0003-1796-0318

Centro Universitário de João Pessoa Unipê, Departamento de Fonoaudiologia, João Pessoa, Paraíba, Brasil.

2 Centro Universitário de João Pessoa Unipê, Curso de Fonoaudiologia, João Pessoa, Paraíba, Brasil.

${ }^{3}$ Universidade Federal da Paraíba - UFPB, Curso de Fonoaudiologia, João Pessoa, Paraíba, Brasil.

Universidade Federal da Paraíba - UFPB, Departamento de Fonoaudiologia, João Pessoa, Paraíba, Brasil.

This project was carried out at the Departamento de Fonoaudiologia do Centro Universitário de João Pessoa - UNIPÊ, João Pessoa, Paraíba, Brasil.

Conflict of interests: Nonexisten

\section{(c) (i)}

Received on: February 6, 2020 Accepted on: May 7, 2020

Corresponding address:

Chirlene Santos da Cunha Moura

Centro Universitário de João Pessoa -

Unipê, Departamento de Fonoaudiologia

Cidade Universitária - Campus I -

Castelo Branco

CEP: 58051-900 - Joao Pessoa, Paraíba

Brasil

E-mail: chirlene.cunha@unipe.edu.br

\section{ABSTRACT}

Purpose: to investigate the inclusion of Educational Speech-Language Pathology in the curricula of Speech-Language Pathology programs in Brazil.

Methods: a descriptive, exploratory, documentary research based on information from public domain documents. Data were collected from the search on the website of the Conselho Federal de Fonoaudiologia, each institution's curricula being analyzed.

Results: a total of 72 higher education institutions in Brazil, offering a SpeechLanguage Pathology bachelor program, was found. Of those that had their curricula available on the website, 34 offered at least one course on Educational SpeechLanguage Pathology. In most institutions, such courses had a study load of 40 hours or more, and $87.88 \%$ were exclusively theoretical.

Conclusion: the presence of Educational Speech-Language Pathology in the curricula represents a progress. However, there is still a long way to go and there are many adjustments to be made for the speech-language pathologist's training to satisfactorily include the field of education.

Keywords: Speech, Language and Hearing Sciences; Education; Higher Education 


\section{INTRODUCTION}

The relationship between speech-language pathology (SLP) and education exists since SLP emerged as a profession. In almost a century of activities in Brazil - with the profession active and regulated since 1981, it is perceived that speech-language pathologists, due to multiple reasons, including the unfamiliarity with programs and public policies, have drifted away from the field of education and overlooked it, as they settled as health professionals ${ }^{1}$.

However, it should be emphasized that such distancing has taken place especially in the theoretical field, as the SPL university programs - grounded on physician-centered models that were the rule at the time when they were developed, and that still today have a strong bias in the fields of health - based their training mainly on prevention practices, focusing on the normal/pathological dichotomy ${ }^{2-4}$.

The school itself never stopped being a field of action for the speech-language pathologist. The Federal Speech-Language Pathology Council (Conselho Federal de Fonoaudiologia - CFFa) published in 2005 the resolution no. $309^{5}$ to legitimize this professional's practice in the educational setting; then, in 2010, at last, it regulated Educational SLP through resolution $387^{6}$.

The work of the educational speech-language pathologist is mainly aimed at promoting education and learning through actions directed to the school community in the different stages of life. To this end, they consider the socio-educational reality of those involved, based on studies involving that population's health and education context? .

It must be kept in mind that, traditionally, the speechlanguage training has emphasized this professional as the one certified to identify, diagnose, and treat people with disorders related to oral and written communication, voice, hearing, orofacial motor functions, and others. For this reason, in education, it is common that their work goals be related to these verbs, although still grounded on prevention. From an educational standpoint, this pathologist must move away from purely clinical conceptions and invest in health promotion ${ }^{8}$, through practices that ensure quality education and significant learning.

It is undeniable that this professional's specific knowledge related to the acquisition of reading and writing, oral language, voice, and hearing can contribute to the school's educative process, establishing a strong interface between education and health. Nevertheless, the speech-language pathologist must be seen as part of an interdisciplinary team, and, to this end, they must set their goal on working with education - not only for education, as it traditionally happens. Hence, the educational speech-language pathologist can work in partnership with the school's pedagogical team or directly with the children in all levels and modes of education. This professional's understanding of the processes aimed at health promotion is closely connected to the quality of education and characterize the importance of the dialogue between the fields of SLP and education?.

The resolution that regulates this specialty enables the educational speech-language pathologist to work in a wide range of possibilities. Despite this, such practice is still noticeably discrete and incipient in Brazil. According to the CFFa, approximately ten years after this specialty was recognized, only 102 professionals are currently specialized in educational SLP ${ }^{10}$ in this country - i.e., no more than $1.37 \%$ of Brazilian speechlanguage pathologists.

Considering this situation, the question arises as to the space given in speech-language pathology training to foment educational speech-language pathology as a specialty, as well as how such a space has been used in this professional's training.

Therefore, it is necessary to reflect on how education-related themes and the very practice of educational SLP are being approached during this professional's training. Thus, this study aimed to investigate the inclusion of educational SLP in the curricula of SLP programs in Brazil.

\section{METHODS}

This is a descriptive, exploratory, documentary study, whose data was electronically collected through the search on the curricula of SLP programs, to investigate their components related to educational SLP. Although it was not necessary to submit the research to the ethics committee, it should be highlighted that the academical institutions researched didn't have their names revealed, neither were they coerced to provide information or be in contact with the researcher to cooperate with this research. All the information obtained concerning it will remain confidential, ensuring the institutions' protection and image.

This research was based on public domain documentary information, collected from the search on the CFFa website, in which the curricula of SLP programs in Brazil were surveyed. The data collection took place from June to August 2018, and the research 
sample comprised the higher education institutions (HEls) presented on the CFFa website.

The inclusion criteria were:

- Being listed among the institutions that offered the SLP program, as presented on the CFFa website;

- Having its website operational at the time of the collection;

- Having the curricula available for consultation.

The exclusion criterion was the failure to meet the abovementioned requirements. Hence, the institutions whose websites were not available at the time of the research, or that did not have the curricula available for consultation were excluded from the study.

The data collection was conducted in two stages. In the first one, the institutions presented on the CFFa website were searched; in the second stage, the curricula on the HEl websites were analyzed, considering the following variables: 1) verification of the existence of courses related to educational SLP as a specialty; 2) investigation of the relationship between theory and practice in the courses approaching educational SLP; 3) analysis of these course's study load.

It is important to emphasize that, although the practical aspects of educational SLP are quite near the field of language, especially reading and written language, it is considered that in the speechlanguage pathologist's training the courses aimed at these areas traditionally approach clinical practice. Therefore, this study considered only those courses named "Educational and/or School Speech-Language Pathology". Courses on oral and/or written language were not included in the corpus of the research to be analyzed.

Based on the survey conducted on the curricula of the institutions whose address was available on the CFFa website, 72 (seventy-two) universities/colleges were found throughout Brazil that offered the SLP bachelor program.

Of these, 34 (thirty-four) institutions had at least one course related to educational SLP in its curricula, whereas 23 (twenty-three) of them had no courses related to this area. As for the other 15 (fifteen) institutions, their website was not available at the time of the research. This number is relevant, as it represents approximately $20 \%$ of the brazilian institutions that offered the SLP program.

\section{RESULTS}

The results of the research show that the $2^{\text {nd }}$ and $4^{\text {th }}$ Regions of the System of Speech-Language Pathology Councils hold the greatest number of HEls offering the Speech-Language-Pathology Undergraduate Program, each of them with $14 \mathrm{HEls}$, as seen in Table 1.

Table 1. Distribution of higher education institutions in Brazil that offer a Speech-Language Pathology program, by regions of the Federal Council of Speech Language Pathology (Conselho Federal de Fonoaudiologia - CFFa)

\begin{tabular}{ccccccc}
\hline & \multicolumn{2}{c}{ Public HEIs } & \multicolumn{2}{c}{ Private HEls } & \multicolumn{2}{c}{ Total } \\
\cline { 2 - 7 } & $\mathbf{N}$ & $\mathbf{0}$ & $\mathbf{N}$ & $\%$ & $\mathbf{N}$ & $\%$ \\
\hline 1st Region & 02 & 28.6 & 05 & 71.4 & 07 & 9.7 \\
2nd Region & 08 & 57.1 & 06 & 42.9 & 14 & 19.4 \\
3rd Region & 03 & 25 & 09 & 75 & 12 & 16.7 \\
4th Region & 07 & 50 & 07 & 50 & 14 & 19.4 \\
5th Region & 01 & 25 & 03 & 75 & 04 & 5.6 \\
6th Region & 02 & 33.3 & 06 & 66.7 & 08 & 11.1 \\
7th Region & 03 & 42.9 & 04 & 57.1 & 07 & 9.7 \\
8th Region & 01 & 16.7 & 05 & 83.3 & 06 & 8.3 \\
\hline Total & $\mathbf{0 1}$ & $\mathbf{3 7 . 5}$ & $\mathbf{4 5}$ & $\mathbf{6 2 . 5}$ & $\mathbf{7 2}$ & $\mathbf{1 0 0}$ \\
\hline
\end{tabular}

Captions: HEls - Higher Education Institutions

Source: CFFa. 
The results reveal that, by region, there is a greater proportion, in general, of HEls with Speech-Language Pathology Programs that include a course related to Educational SLP in their curricula (Table 2).

It was verified that the $7^{\text {th }}$ Region of the System of Speech-Language Pathology Councils - which encompasses Rio Grande do Sul - has proportionally the greatest number of HEls offering courses related to Educational SLP, as five (71.42\%) out of the seven HEls listed in that Region meet this criterion. In the $3^{\text {rd }}, 1^{\text {st }}$, and $5^{\text {th }}$ Regions, the proportion of HEls with such courses is equal to or over $50 \%$. There is also a discrepancy to be considered, in which some regions with a great number of institutions with Speech-Language Pathology programs have only a few of them offering courses on Educational SLP in their curricula, as seen in Table 2. In this sense, the $8^{\text {th }}$ Region - comprising four states: Rio
Grande do Norte, Ceará, Piauí, and Maranhão - stands out with the lowest index (33.33\%). There are six institutions in this region offering the SLP program, but only two of them have a course approaching Educational SLP in their curricula.

The data related to the $9^{\text {th }}$ Region were not described on the CFFa website at the time of the collection, so they were not reported in this study. According to the CFFa, the $9^{\text {th }}$ Region (which had been recently created at the time of the research) encompasses six states in Northern Brazil - Acre, Amapá, Amazonas, Pará, Rondônia, and Roraima - that used to belong to the $5^{\text {th }}$ Region. This new arrangement meets the need for drawing speech-language pathologists nearer their Regional Councils, which that part of the country had long been requesting.

Table 2. Description of Educational Speech-Language Pathology courses in the curricula of Speech-Language Pathology programs in colleges and universities, throughout Brazil

\begin{tabular}{ccccc}
\hline Region & Offering an ESLP course & $\begin{array}{c}\text { Not offering an ESLP } \\
\text { course }\end{array}$ & Website unavailable & \% per Region \\
\hline 1st & 4 & 2 & 1 & $57.14 \%$ \\
2nd & 5 & 6 & 3 & $35.71 \%$ \\
3rd & 7 & 2 & 3 & $58.33 \%$ \\
4th & 6 & 5 & 3 & $42.85 \%$ \\
5th & 2 & 2 & 0 & $50.00 \%$ \\
6th & 3 & 3 & 2 & $37.05 \%$ \\
7th & 5 & 1 & 1 & $71.42 \%$ \\
8th & 2 & 2 & 2 & $33.33 \%$ \\
9th & 0 & 0 & 0 & $00.00 \%$ \\
\hline Total & $\mathbf{3 4}$ & $\mathbf{2 3}$ & $\mathbf{1 5}$ & \\
\hline
\end{tabular}

Captions: ESLP: Educational Speech-Language Pathology

The character (theoretical, practical, or theoretical/ practical) of the courses related to the specialty of Educational SLP were evaluated. The proportion of theoretical classes is noticeably greater in the institutions researched (Table 3).

Table 3. Total number of institutions offering practical classes in the courses of Educational Speech-Language Pathology

\begin{tabular}{lcc}
\hline Approach of the course & No. of Institutions & $\%$ \\
\hline Exclusively theoretical & 29 & $87.88 \%$ \\
Exclusively practical & 2 & $6.06 \%$ \\
Theoretical and practical & 3 & $6.06 \%$ \\
\hline Total & $\mathbf{3 4}$ & $\mathbf{1 0 0 \%}$ \\
\hline
\end{tabular}


Regarding the study load, the research shows that, in $69.70 \%$ of the HEls offering courses that approach
Educational SLP, these have more than 40 class hours (Table 4).

Table 4. Total study load of the Educational Speech-Language Pathology courses

\begin{tabular}{ccc}
\hline Study load & No. of institutions & $\%$ \\
\hline$<40$ hours & 23 & $69.70 \%$ \\
$>40$ hours & 11 & $30.30 \%$ \\
\hline Total & $\mathbf{3 4}$ & $\mathbf{1 0 0 \%}$ \\
\hline
\end{tabular}

\section{DISCUSSION}

The interface between SLP and education is not recent. Given the limitations of regional, cultural, and linguistic differences, the records of activities of the first speech-language pathologists were mostly related to school-related problems, such as communication and comprehension difficulties. These have always been a matter of concern and challenge for educators, as they have a great influence on learning issues ${ }^{2-4,8}$.

Still today, many education professionals state that they are not prepared to deal with these issues and frequently look for help from speech-language pathologists. Despite the close relationship between the two fields dating from the beginning of the practices inSLP, even being one of its landmarks, EducationalSLP was only regulated as a specialty by the CFFa in $2010^{1,8,11,12}$.

After almost ten years since its regulation as a specialty, and especially considering the history of the profession, the fact that, currently, less than $50 \%$ of the institutions offeringSLP programs in Brazil have courses approaching EducationalSLP calls attention. It is understood that the interest and work in a specific field can be directly influenced by the experiences lived during one's undergraduate years. Therefore, the training has an important role both in the visibility educational SLP has in its field and the recognition given this professional by peers in related areas, particularly in education.

Moreover, it is necessary to highlight that the great majority (87.88\%) of the HEls that offer the course has only a theoretical approach, with a study load of 40 hours - or oftentimes a little more than that. According to the recommendations from the National Health Council (Conselho Nacional de Saúde - CNS) and the national curricular guidelines, the SLP bachelor programs must have a minimum study load of 4,000 (four thousand) hours in the traditional in-class mode, with training that includes experiences of contact with real-life situations ${ }^{13}$. It is known that the 4,000 hours recommended by the CNS must encompass a generalist training, which enables the student who fully completes them to be apt to work with excellence in any of the fields of SLP. However, there should be a reflection on the meaning and possibilities presented by the training in the format currently offered. What does a course of little more than 40 hours approaching educational SLP mean and make possible in a universe of at least 4,000 hours, mostly aimed at identifying and (re)habilitating pathologies?

It is notorious and legitimate that speech-language pathologists increasingly seek recognition as professionals that can also work in partnership with education. However, for that to happen, it is further necessary that this professional be well prepared. In other words,SLP training should equally enable this professional to work in partnership with education, surpassing the limits historically imposed - as they used to have the role, within the school, of identifying communication problems and setting goals to prevent them ${ }^{8,11}$.

Currently, the society has been moving - although often with slow steps - towards respecting and recognizing diversity. Concerning education, the inclusionrelated public policies have also emphasized and sought alternatives and solutions for the different learning methods. Many of the proposals involve changes in concept, in the effort to develop a new meaning to activities involving differences and give these a status within the educational setting.

Hence, the speech-language pathologist that intends to work in the field of education must acquire knowledge beyond the alterations manifested at school, and approach the legislation that regulates that environment, the different teaching methodologies and theories, and the particularities of each different place. Working in public schools certainly has different demands from those found in private schools, for 
instance. Furthermore, the work developed in each institution must be connected to the social, historical, and cultural context to which it belongs.

Nevertheless, for this to happen, education needs to be seen, understood, and experienced from a new perspective, one that broadens the visual field, strategies, and actions that have been traditionally aimed exclusively at language alterations that are manifested at school ${ }^{11,12}$.

Thus, it is suggested that the educational speechlanguage pathologist work beyond instructing students and teachers, with an exclusive focus on language alterations - either to prevent or identify them and proceed with the necessary referrals. The work to be performed by the educational speech-language pathologist, above all, must have in view a horizontal relationship between the fields of knowledge, to together develop the identification of each context's specific demands, leading to a more dynamic teaching-learning process ${ }^{14}$.

Furthermore, this professional needs to understand the circumstances present beyond the school walls and be enabled to work with them. The educational speechlanguage pathologist's practice must also take the school's management staff into account, as well as the community. The pathologist's planning in partnership with this staff, and education professional's continuing education are examples of practices legitimized by the CFFa for the educational speech-language pathologist ${ }^{6,15}$. However, in practical terms, it can be stated that such spaces have been seldom occupied.

According to a study based on the BrazilianSLP journals ${ }^{16}$, the speech-language pathologist is mostly focused on identifying and (re)habilitating children's alterations - i.e., most of the time, this professional's practice, even in educational institutions, is still guided by a clinical perspective. This seems to reflect the speech-language pathologists' training, which does not yet properly enable them to work otherwise or to broaden their practice in partnership with the field of education - as verified by the data presented in this study. It is also important to highlight that the number of speech-language-pathologists integrating multidisciplinary teams in schools is still considered low, as their professional contribution is often given only as a consultant. Moreover, it cannot be forgotten that their range of professional possibilities still fails to be known and acknowledged - both by educators and speechlanguage pathologists themselves. Such factors certainly contribute to the low number of actions carried out in the field of educational management.
Another aspect to be considered is the quality of the experiences the SLP undergraduates have in the field of education throughout their training. As previously reported, the great majority of courses are exclusively theoretical. While recognizing the fundamental importance of the theoretical basis to any practice, the not less important role of practical experience in learning cannot be neglected, especially during professional training. The practical experience is important as it offers the students a stronger interaction with their physical and social environment, leading them to apprehend faster the theoretical information ${ }^{17}$. It also leads professors to the initiative of more dynamic teaching, integrating the students to the context, helping them understand themselves and the world being presented them, resulting in faster acquisition of knowledge.

The practical classes help develop scientific concepts, besides enabling students to perceive how to approach their future world, which lies outside the classroom, and how to find solutions to complex problems in their field. Also, these classes are a strategy to instill a new perspective on a given issue ${ }^{18}$.

Therefore, it is necessary to reflect whetherSLP training has opened the way for the student to work in the educational field beyond the limits of clinical practice. This would enable the student to both get acquainted with and reflect on situations that could take place in such contexts, besides speech-language alterations manifested at school. Certainly, the HEls that offer Educational SLP courses in their undergraduate programs provide the students more work-related knowledge, which in turn broadens their possibilities to work in the field, strengthening educational SLP in the country. Nonetheless, it is still necessary to investigate and reflect whether the theoretical and methodological bases used in such courses give room to an educational view - redirected from the clinical view traditional approached - committed with promoting a quality education above anything else.

It is, thus, an urgent matter that this field begin to be scientifically intensified, especially with research that portrays the experiences of educational speechlanguage pathologists that are promoting education and learning, in detriment of those grounded on a clinical perspective, mainly using the educational institutions as the context where to collect the data regarding speech-language assessments and diagnoses. 


\section{CONCLUSION}

Based on the results of this research, it was concluded that including a course approaching EducationalSLP as a specialty in the curricula of SLP programs is a significant progress in this professional's training. However, there is still a long way to go and there are adjustments to be made within the institutions for the actions of the speech-language pathologist not to be restricted to health, but opened, too, to the demands of the country's educational system, no longer overlooked as an option for this professional's work.

Further research on the inclusion of educational SLP in the curricula ofSLP university programs in Brazil is necessary, to update data, and to make people aware of the importance of the work done in this field. Hence, the institutions will be able to show the undergraduate SLP students a new work possibility, which can be done in partnership with the schools. Therefore, it is necessary to deepen the study on the goals and practices experienced during the EducationalSLP courses. It is, thus, urgent that the educational speechlanguage pathologists define and accept their identity to broaden their practices, giving them new meaning and legitimacy.

\section{REFERENCES}

1. Queiroga BAM. Bons motivos para investirmos na Fonoaudiologia Educacional. In: Queiroga BAM, Zorzi JL, Garcia V (orgs). Fonoaudiologia Educacional: reflexões e relatos de experiências. Brasília: Editora Kiron; 2015. p.44-53.

2. Berberian AP. Fonoaudiologia e Educação: um encontro histórico. São Paulo: Plexus, 2ª ed; 2007.

3. Figueiredo Neto L. $O$ início da prática fonoaudiológica na cidade de São Paulo-seus determinantes históricos e sociais [Dissertação]. São Paulo (SP): Pontifica Universidade Católica de São Paulo - PUC/SP, Faculdade de Fonoaudiologia; 1988.

4. Bortolozzi KBB. Fonoaudiologia e Educação: a construção de uma parceria responsiva ativa [Tese]. Curitiba (PR): Universidade Tuiuti do Paraná; 2013.

5. Conselho Federal de Fonoaudiologia. Resolução № 309, 01 de abril de 2005. Dispõe sobre a atuação do Fonoaudiólogo na educação infantil, ensino fundamental, médio, especial e superior, e dá outras providências. Brasília; 2005. Disponível em: https://www.fonoaudiologia.org.br/resolucoes/ resolucoes_html/CFFa_N_309_05.htm

6. Conselho Federal de Fonoaudiologia. Resolução № 387, 18 de setembro de 2010. Dispõe sobre as atribuições e competências do profissional especialista em Fonoaudiologia Educacional reconhecido pelo Conselho Federal de Fonoaudiologia, alterar a redação do artigo 1ㅇ da Resolução CFFa no 382/2010, e dá outras providências. Brasília; 2010. Disponível em: https://www.fonoaudiologia.org.br/resolucoes/ resolucoes_html/CFFa_N_387_10.htm

7. Celeste LC, Zanoni G, Queiroga B, Alves LM. Hearing and Speech Sciences in Educational Environment Mapping in Brazil: education, work and professional experience. CoDAS [periódico na internet]. 2017 [acesso em: 14.04.2020]; 29(1): [7p.]. Disponível em: http:// www.scielo.br/pdf/codas/v29n1/en_2317-1782codas-2317-178220172016029.pdf

8. Figueirêdo LC. O outro na escola: algumas representações a respeito das diferenças [Tese]. Campinas (SP): Universidade Estadual de Campinas - UNICAMP, Instituto de Estudos da Linguagem; 2015.

9. Cabral ILA, Gomes IC. A importância da Fonoaudiologia no âmbito educacional. Rev Cient. InFOC. 2017;2(1):40-5.

10. Consulta especialistas por especialidade/região [homepage da internet] Brasília: Conselho Federal de Fonoaudiologia. 2020 [acesso em: 29.03.2020]. Disponível em: https:// www.fonoaudiologia.org.br/cffa/index.php/ consulta-especialistas-por-especialidaderegiao/

11. Figueiredo LC, Lima ILB, Silva HSE. Representations of educational professionals for Speech, Language and Hearing Sciences practice in schools. Distúrb Comun. [periódico na internet]. 2018 [acesso em: 14.04.2020]; 30(1):[8p.]. Disponível em: https:// revistas.pucsp.br/dic/article/view/32254/25281

12. Lima ILB, Delgado IC, Lucena BTL, Figueiredo LC. Contributions of the institutional diagnosis for speech language pathology and audiology practice in schools. Distúrb Comun. [periódico na internet]. 2015 [acesso em: 14.04.2020];27(2):[11p.]. Disponível em: https://revistas.pucsp.br/dic/article/ view/19765/17407

13. Conselho Nacional de Saúde. Resolução n610, 13 de dezembro de 2018. Recomendações do Conselho Nacional de Saúde (CNS) à proposta 
das diretrizes curriculares nacionais do curso de graduação bacharelado em Fonoaudiologia; 2018.

14. Gertel MCR, Tenor AC. Educational Speech, Language Pathology and Audiology: considerations on the medicalization of education. Distúrb Comun. [periódico na internet]. 2018 [acesso em: 14.04.2020];30(4):[12p]. Disponível em: https:// revistas.pucsp.br/dic/article/view/36349

15. Conselho Regional de Fonoaudiologia - 2a Região. Fonoaudiologia na Educação: políticas públicas e atuação do fonoaudiólogo. 2010.

16. Berberian AP, Ferreira LP, Jacob LC, Azevedo JBM, Mendes JM. A produção de conhecimento em Distúrbios da Comunicação: análise de periódicos (2000-2005). Rev Soc Bras Fonoaudiol. 2009;14(2):153-9.

17. Baptista GCS. A importância da reflexão sobre a prática de ensino para a formação docente inicial em ciências biológicas. Ensaio Pesquisa em Educação em Ciências. 2003;5(2):86-96.

18. Leite ACS, Silva PAB, Vaz ACR. A importância das aulas práticas para alunos jovens e adultos: uma abordagem investigativa sobre a percepção dos alunos do PROEF II. Ensaio Pesquisa em Educação em Ciências. 2005;7(3):166-81.

\section{Erratum}

In the article, "Educational Speech-Language Pathology in the curricula of Speech-Language Pathology Programs in Brazil", with DOI number: $10.1590 / 1982-0216 / 20202231320$, published in the journal Revista Cefac 2020;22(3):e1320, in the author's name (page 1):

Where it was:

Chirlene dos Santos da Cunha Moura

Read:

Chirlene Santos da Cunha Moura 